\title{
THE POSTNATAL REVIEW: THE TASK OF THE MIDWIFE
}

\author{
C.A. Benn, W.J. Kotzé and A.G.W. Nolte
}

\begin{abstract}
There is growing realization that wamen's heallh and involvement in health care are essential keys to health for all. Ore way in which the midwifery profession can contribute to women's health is by providing high quallyscare during the six week postnat at review/checkup, A study in three provinciallhospitals in the Pont Elizabeth area showed that the octuat structure of the posmaral review fell far short of the ideal as specified by the literature. Of all the elemervs included in the ideal postnatal review, only $23,5 \%$ of these were performed or supervised by the midwife. Seventy percent (70\%) of these elements were not performed at all thus emphasising the fact that a comprehensive health service is not being provided at the postnatal clinics in Port Elizabeth.
\end{abstract}

\section{Abstnak}

Daar is 'n groeiende bewuswording vart die feit dar die gesondheid en betrokkenheid van wroue by gesondheidsorg sleurelbegrippe is vir die berelking van gesoudheid deur aimal. Een wyse waarop die vertoskunde beroep 'n bydrae kan lewer tot die gesondheid van uroue is die woorsiening van hol gehalte diens gedizende dic ses weke nageboorte-ondersoek 'n Navarsingsstudtie in drie provinsiale haspitale is die Port Elizabeth omgewing het aangedui dat die werklike struktuurvan die nageboorte-ondersoek ver onder die ideaal soos gespesifiseer in die literatrur, geval het. Slegs $23,5 \%$ van al die aspekte wat in die ideale nageboorte-ondersoek ingertuit is, is deur die vroedwou self of onder haar toesig gedaen. Sewentig persent (709) van die aspekte was glad nie gedoen nie, war beklemtoon dat die nageboorteklinieke in Pont Elizabeth nie ' $n$ omvattende gesondheiddiens lewer nie.

\section{INTRODUCTION}

Women's heal th and involvement in heal th care are essential keys to health for all. If the women of a nation are healthy and health conscious, then their families, their community and the nation will tend to be healthy too.

Midwives are involved intimately in the provision of health care for women prenatally, intranatally and postnatally. Of these three areas postnatal care may be regarded as the "Cinderella of the maternity services" (Barnett 1984:360). The reasons for this may be that there is no high technological intervention in the postnatal wards and that postnatal care as the responsibility of the midwife has remained under medical control, especially in the hospital (Rider 1985:27). Despite the general impression held by most midwives that postnatal care is uninteresting, it can make a meaningful contribution to reduction in maternal and infant morbidity and mortality.

Although in-hospital postnatal care is a secondary health service, the health education which can be disseminated to the new parents in that situation is a vital primary health service in the sense that parents are being equiped to provide health care for their family at home. However, the six week postnatal review performed by a general practitioner, obstetrician, or by a clinic is a primary health service in the true sense of the word.

Unfortunately the six week postnatal review is not attended by all postpartum women as was evidenced by statistics obtained from 3 postnatal clinics in the Port Elizabeth area. In 1989 an average of 3900 deliveries occurred at the provincial hospital which offers a postnatal clinic service, but an average of only 323 women $(8,2 \%)$ returned for postnatal review at six weeks. Possible reasons for this may be that they do not have the time to wait to see the doctor, that they have returned to work, that the women lack knowledge regarding the importance thereof, or because of the small benefit they reaped from contact with health care providers in terms of information and education received and emotional support given. Coetzee (1988:1-15) in her background study into the maternity services in South Africa found that aspects presenting major problems in providing postnatal care were patient co-operation (46\%) and transport (47\%), as well as a deficiency in the skills of the midwives with regard to community oriented services.

If primary health services were utilized effectively by both patients and care givers alike, a valuable contribution to the heal th of the mother and the child and ultimately to the health of the nation as a whole could be made. According to Bowers (1985:1114) maternal morbidity could be an extremely useful measure for evaluating midwifery and obstetric care, but little attention has been paid to the health or ill-health of mothers between pregnancies. In a conference on Safe Motherhood held in Kenya in 1987, Dr Fred Sai (1987:1) called for maternal health care to be made "a priority within the context of primary health care services and overall development policy".

Therefore, in order to determine whether postnatal clinics in Port Elizabeth are meeting the health and educational needs of mothers postnatally, and to clarify the task of the midwife in providing this comprehensive health service, a study was undertaken to investigate the six week postnatal review.

\section{RESEARCII OBJECTIVES}

The objectives of this research were to:-

determine the tasks which should be included in the postnatal review

determine the present task of the midwife with regard to the six week postnatal review

develop guidelines for the management of the posinatal mother and child visit to the clinic for their six week postnatal review.

\section{LIMITATIONS OF TIIIS STUDY}

The quality of the care received during the conduct of the six week postnatal review was not the focus of this study, but was rather the present task of the midwife in terms of what aspects are, and should be, included in the review. The study was concentrated in the Port Elizabeth area and thus results cannot be necessarily extrapolated to other centres in the country. 


\section{LTTERATURE STUDY}

An extensive study into the postnatal health needs of the mother-child dyad and the role of the midwife in meeting these needs was done. The literature studied was also used in the design of the observation instrument for the empirical study.

\section{EMPIRICAL STUDY}

In order to gather data regarding the present task of the midwife during the six week postnatal review, three provincial hospitals in the Port Elizabeth area were selected. These were designated as Areas 1, 2, 3 in order to maintain confidentiality. Areas 1 and 3 are two of the hospitals serving mainly the black, Asian and coloured population groups in Port Elizabeth and Area 2 served mainly the white group. In Areas 1 and 3 the postnatal review is conducted by the midwife who refers the patients to a doctor when necessary. In Area 2 the midwife assists the doctor during the examination of the patient.

After guaranteeing patient privacy and confidentiality and supplying the Head Office of the Cape Provincial Department of Hospital Services with the objectives of the research, permission was granted to proceed with data collection. Permission also was obtained from the Medical Superintendent and the Senior Nursing Service Manager of each hospital before the study was commenced.

\section{RESEARCH INSTRUMENT}

An observation schedule was designed by the researcher, using various nursing and medical references regarding the six week postnatal review (Clayton, Fraser and Lewis 1972:158 \& 159 Hallum 1976:86; Moor and Strickland 1983:940-945; Bourne 1984:439-444; Chamberlain 1984:248 \& 249; Williams 1986:197-199;). The instrument depicting the ideal structure of the six week postnatal review, indicated which aspects should be examined during the conduct of the review.

In order to determine the present task of the midwife with regard to the six week postnatal review as compared to what it should be as indicated by the observation schedule designed, the researcher had to follow a women through the clinic proceedings from her arrival to her departure; this was done in order to determine what was done to, and for her, and by whom it was done.

The schedule was used as a checklist and handled by the researcher only; it was not utilized as a questionnaire. During her observation of the management of a posinatal patient at the six week review, the researcher indicated in the appropriate column whether an activity was performed by a registered or student midwife, and if not, by whom it was performed. If an aspect was not applicable to a particular mother, for example, she had no abdominal wound as she had had a vaginal delivery, this was indicated in the "Not Applicable' column. Anything not done by anyone was indicted in the 'Not Done' column.

In order to increase reliability and decrease observer variability in interpretation and recording, the researcher personally collected all data for the study. This took place from September 1, 1989 to February 28, 1990.

\section{RESEARCII POPULATION}

Selection of the research population was based on the number of patients attending the postnatal clinic each month in the three study hospitals. Monthly postnatal clinic attendance statistics for the three hospitals were obtained for the years 1985 - 1989 and the average attendance over the year concerned was calculated. The Exponential Smoothing Model for Forecasting (Grobbelaar in Wolvaardt, Smith, Rubinstein and Grobbelaar 1984:175-184) was used to determine the size of the research population based on the attendance statistics.

In order to calculate the number of patients to be used in the study the estimated and actual attendances during 1989 was totalled for each hospital.

Based on the above totals, the size of the research population from each hospital was determined by calculating the 1989 clinic attendance statistics as a percentage of the total attendance for the three hospitals.

TABLE 1

ESTIMATED AND ACTUAL ATTENDANCE AT THE POSTNATAL CLINICS FOR 1989

\begin{tabular}{|l|c|c|}
\cline { 2 - 3 } \multicolumn{1}{c|}{} & $\begin{array}{c}\text { Estimated At- } \\
\text { tendance }\end{array}$ & $\begin{array}{c}\text { Actual Attend- } \\
\text { ance }\end{array}$ \\
\hline Area 1 & 362 & 377 \\
\hline Area 2 & 144 & 133 \\
\hline Area 3 & 517 & 460 \\
\hline TOTAL & 1023 & 960 \\
\hline
\end{tabular}

As the study was commenced during 1989 the estimated sample size was used giving a total sample of 100 patients. These were selected conveniently; any patient (regardless of age, parity or type of delivery) attending the postnatal clinic whom the researcher could observe during the postnatal examination from the patient's arrival to her departure, and who gave her consent was eligible for inclusion. The only patients excluded from the study were those who were menstruating at the time of their clinic visit as the postnatal checkup/review was not performed on them.
TABLE 2

ESTIMATED SAMPLE SIZE AND CALCULATED ACTUAL CLINIC ATTENDANCE FOR 1989

\begin{tabular}{|c|c|}
\hline $\begin{array}{c}\text { Estimated Sample } \\
\text { Slze for 1989 as } \\
\text { used in the study }\end{array}$ & $\begin{array}{c}\text { Calculated actual } \\
\text { clinic attendance } \\
\text { for 1989 } \\
\text { (as of the total) }\end{array}$ \\
\hline Area 1 = 35 & 39 \\
\hline Area 2 = 14 & 14 \\
\hline Area 3 = 51 & 47 \\
\hline Total = 100 & 100 \\
\hline
\end{tabular}

\section{SYNTIIESIS OF RESEARCII FINDINGS AND LITERATURE REVIEW.}

The data collected were collated using the Lotus 1-2-3 computer package and calculations were made. The following is a descriptive analysis of the findings.

Research into the six week postnatal review has revealed that utilization of this service is relatively poor. This also was the case in England until Dennison (1979) improved attendance rates to almost $100 \%$ by holding baby clinics at the same time as the postnatal clinics (Bowers, 1985:1115). In this particular work, clinic attendance at the three study hospitals also indicated poor utilization of the services offered. Although the researcher dif not investigate this aspect, it appears that reasons for poor attendance may be similar to those discovered by Coetzee (1988:1-15) in her investigation into the postnatal services in the four provinces essentially transport problems, waiting for long periods of time to receive a brief examination, and poor patient co-operation.

When comparing the ideal structure of the six week postnatal review (Figure 1) as identified in the literature, (irrespective of who carries it out) with the actual structure (Figure 2) as observed in the 3 hospitals under study, it was found that actual structure falls far short of the ideal.

The greatest emphasis was on the physical examination of the mother $(64,9 \%)$ and least emphasis was on the interview $(12,8 \%)$, and on the education of the mother $(2,0 \%)$. Although other aspects such as physical examination of the baby, history-taking, recording, referral and treatment were closer to the ideal when considering all areas researched, deficiencies were identified in individual areas. For example, in Areas 1 and 3 the physical examination was not performed for any of the babies who accompanied their mothers to the clinics.

Each aspect included in the ideal structure of the six week posinatal review was considered individually for all the areas researched in order to determine the present task of the midwife during this review. 


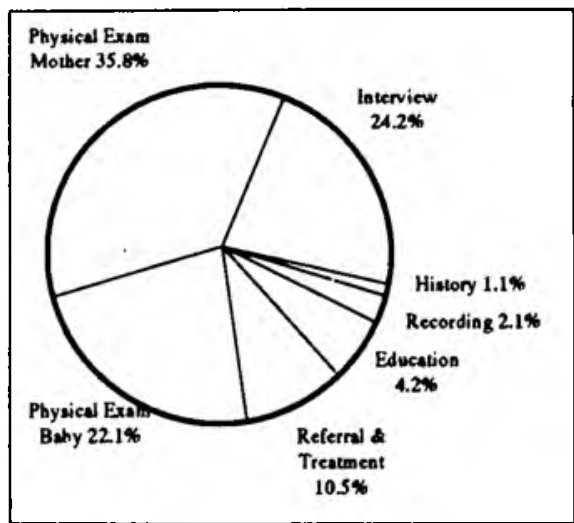

Figure 1

Ideal Structure of Postnatal Review

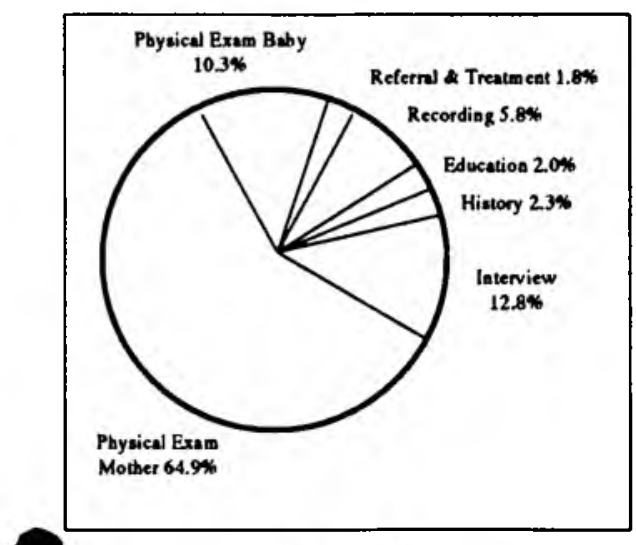

Figure 2

Total Area

Actual Structure of Postnatal Review

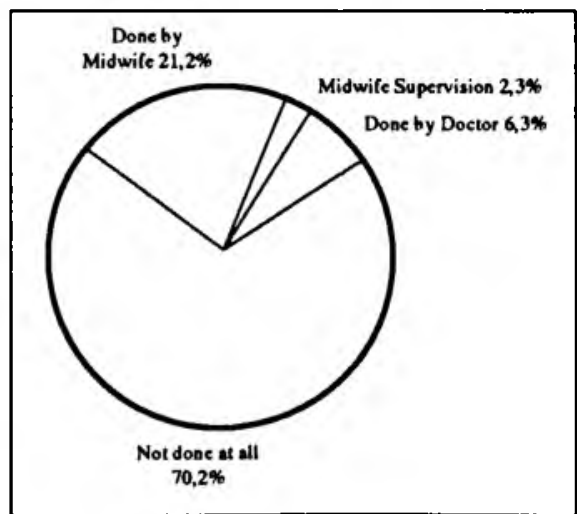

Figure 3

Combined Observations

All Areas

The obtaining of a history, or the supervision thereof, by a midwife was done in $44 \%$ of available opportunities, but not obtained at all in $51 \%$ of the opportunities. Thus possible problems, arising from the pregnancy and labour which needed to be followed up, were missed.

Only $11,2 \%$ of the opportunities for interviewing the patients were either done or supervised by the midwife, while $87,8 \%$ of the opportunities were not used at all. A closer look at the analysis of the research results indicate that the area of greatest neglect was the emotional and social adaptation of the mother, father and siblings to the new baby in the family. These results support the findings of Bowers (1985:1115) and Sleep (1986:72) and may be a reason for postpartum depression going undetected and persisting for sometimes up to three years postpartum (Handford 1985:30-33), and for increased child neglect and abuse in modern society.

Aspects of the physical examination of the mother were not performed in $56,1 \%$ of the opportunities, some of which may have been done if the interview had been comprehensive. The physical examination of the baby was only done by the doctor in Area 2; seventy-eight percent $(78,7 \%)$ of the opportunities were not utilized at all in the three areas investigated. The postnatal service thus was found to be fragmented in the sense that the mothers have to be referred to different clinics for example, in order to have the baby examined or to receive contraception mothers would be obliged to go elsewhere. This increases the costs for the mother and may mean that urgent health needs go untended.

Alhough referral and treatment of patients was done by the midwife in only $24,5 \%$ of all the opportunities available for the 100 patients observed, all the conditions which required referral or treatment were relatively minor and well within the midwife's ability to identify them as problems. This bears out Carsiens (1988:1-52) findings and supports her recommendation that the six week postnatal review should be the task of a trained professional nurse/midwile, who should refer any apparent abnormalities to the doctor. In Area 2 specifically, it was found that the registered midwife, educated at considerable cost to herself and the State, is underutilized in the provision of a comprehensive six week postnatal review.

Researchers (Gruis 1977:186; Adams 1963:22-27) have identified particular concerns of mothers after discharge from hospital. These included infant feeding, infant care and self care with particular emphasis on emotional needs. These concerns were found to be more significant after one week at home. The majority of such needs could be met by adequate education. During this research into the six week postnatal review it was found that the midwife only utilized $10,1 \%$ of the educational opportunities available. Thus an important aspect of primary preventative health care was neglected, as $86,6 \%$ of the opportunities for education were not utilized at all.

Recording of the information obtained during the posinatal examination was done best of all aspects included in the ideal structure. Only $36 \%$ of opportunities were not utilized.

An overall picture of the observations that should be included in the six week postnatal review, as indicated in Figure 1 (the Ideal Structure of the Posinatal Review), demonstrates that $70,2 \%$ of all opportunities available for the 100 patients, from all 3 clinics included in the research, were not utilized at all (Figure 3). That is, neither a doctor, a midwife or another member of the nursing staff performed those tasks.

\section{CONCLUSIONS REGARDING TIIE RESEARCII RESULTS}

This investigation into the conduct of the six week postnatal review, potentially such a valuable primary heal th service, reveals serious shortcomings in the quality of the postnatal service provided by the three provincial hospitals under study.

The six week postnatal review as performed in the three hospitals falls far short of the ideal as specified by the literature.

A comprehensive health service is not being provided for the mother-child dyad during the six week review.

The service is fragmented in the sense that the mothers have to be referred to different clinics in order to have the baby examined or to receive contraception. This increases the cost for the mother and therefore means that urgent health needs may be neglected.

Key aspects, which are vital for healthy life of the mother, child and the family have not been included in the examination, for example the social, psychological and emotional needs of the family, were neglected.

The registered midwife seems uncertain regarding aspects which should be included during the conduct of the six week review.

The registered midwife, recipient of an expensive professional education, is being underutilized in Area 2 in the provision of a comprehensive six week postnatal service.

\section{RECOMMENDATIONS}

Guidelines for the management of the postnatal mother and child visit to the clinic for their six week review were designed. These guidelines may be used as a record sheet of aspects examined and problems identified during the course of the review for each women. They also may be used for providing inservice education for midwives already involved in the provision of a postnatal service. A care plan, which includes aspects to be assessed, potential nursing diagnoses to be made and nursing interventions which may be necessary, as well as detailed information regarding specific aspects of the review, were designed by the researcher. Detailed information provides information on the questions to be asked regarding such aspects as emotional status and sexual intercourse postnatally, as well as giving a detailed explanation regarding the 
performance of various techniques such as bimanual pelvic examination are included. Sections of such detailed information were used to compile an education leaflet which may be given to patients to take home and use as part of the midwife's contribution to primary prevention and the early detection of health problems. The abovementioned are included as the main recommendations arising from the research findings and will be published in future issues of Nursing RSA.

\section{Utilization of Baby Clinics}

The baby clinics could be utilized more effectively in providing a postnatal service for mothers as well as their babies, by having at least one professional nurse at each clinic who is also an experienced midwife.

\section{Utilization of Private Midwifery Practices}

More midwives should be encouraged and assisted in the commencement of a private postnatal practice, as many mothers do not return for their six week review and have no one to turn to for help if they have problems. It is costly for them to visit a doctor every time they have a query or a minor problem, and a midwife in private practice would have more time and specialist knowledge in the postnatal field to assist the mother and her family with their problems.

Personnel Development and Formal Education Programmes

The introduction of a programme to educate the midwife to function specifically in the community in South Africa also would be of assistance in preparing the midwife to provide a desperately needed service to postnatal mothers and their babies. Such a course can be offered as a short course in postnatal care for nurses and midwives or as part of a post-basic Diploma or Honours programme in Midwifery or Community Health Nursing Science. Personnel development programmes may also include aspects of postnatal care in order to improve the service given in hospitals.

Utilization of Mass Media to reach Mothers A radio programme, especially aimed at meeting the health needs of new mothers and answering their problems regarding childrearing and adaptation postnatally, would help bridge the wide gap in the primary health care of mothers.

\section{Further Research}

The researcher recommends that future research regarding postnatal care focus on:

an analysis of the quality of care given to the patients during the conduct of the six week postnatal review after implementation of the guidelines designed as a result of this particular study

reasons for the patients not returning for their six week postnatal review.

the feasibility and viability of local and national radio programmes focusing on the queries and health needs of the postnatal mother and child.

the determination of the health needs of the postnatal mother-child dyad for the design of such a radio programme.

\section{CONCLUSION}

With emphasis in health moving into the field of primary health care, it is essential that the midwife providing a primary health service, whether in the community or in a hospital clinic, or as a private practitioner, be equipped to meet the comprehensive health needs of the mother, child and family. It is the midwife's responsibility to keep her knowledge up to date and to ensure that the information and care given to patients is of a high standard - a standard which is worthy of the respect of society for professional midwives.

\section{BIBLIOGRAPIIY}

ADAMS, M. 1963. in Bull, M. and Lawrence, D. 1984. A Pilot Study: Postpartum Mothers' Perception of the Information Received in the Hospital and its Usefulness During the first Weeks at Home. Journal of Community Health Nursing, 1.2:111-124.

BARNETT, ZITA. 1984. Yesterday, Today and Tomorrow in Postnatal Care. Dame Rosalind Paget Memorial Lecture. Midwives Chronicle and Nursing Notes, November, 97.1162:358-364.

BOURNE, GORDON. 1984. Pregnancy. New and Revised Edition. London: Cassell Lid. 439-444.

BOWERS, J. 1985. Is the Six Week Postnatal Examination Necessary? The Practitioner. December, 229:1113-1115.

CARSTENS, Dr. J.J. 1988. 'n Studie van Nageboorte Ondersoeke in 'n Swart Stedelike Hospitaal. University of Pretoria: Unpublished research paper.

CHAMBERLAIN, G. 1984. Lecture Notes on Obstetrics. 5th Edition. London: Blackwell Scientific Publishers

CLAYTON, S.G., FRASER, D. AND LEWIS, T.L.T. (Editors). 1972. Obstetrics by Ten Teachers. London: Edward Amold.
COETZEE, L. 1988. Obstetric Services in the Republic of South Africa. Pretoria: South African Nursing Association. Unpublished report. $15 \mathrm{pp}$

DENNISON, S. 1979 in Bowers, J. 1985. Is The Six Weeks Postnatal Examination Necessary? The Practitioner, December, 229:1113-1115.

GROBBELAAR, J.W. in Wolvaardt, J.S., Smith, T.H.C., Rubinstein, G. and Grobbelaar, J.W. 1984. Operations Research. Revised Edition. Pretoria: University of South Africa

GRUIS, M. 1977. Beyond Maternity: Postpartum Concerns of Mothers. American Journal of Maternal Child Nursing. May/June, 2.3:182-188.

HALLUM, JEAN. 1976. Midwifery. 2nd Edition. London: Hodder and Stoughton.

IIANDFORD, P. 1985. Postpartum Depression: What is it? What Helps? Canadian Nurse. January, 81.1:30-33.

MOORE, M.L. AND STRICKLAND, O. 1983. Realities in Childbearing. 2nd Edition. London: W.B. Saunders.

RIDER, ANNE. 1985. Postnatal Care: Midwifery after Birth. Nursing Times, August 7, 81.32:27-28.

SAI, FRED T. 1987. The Safe Motherhood Initiative: A Call to Action. International Nursing Review, 34.4:110-111.

SLEEP, J. 1986. Parenthood by Design. Nursing 2. Bailliere Tindall, 3.2:71-74.

WILliaMS, E. (Editor). 1986. Prosedure Handleiding by Verloskunde. Pretoria: HAUM Publishers. 197-199.

C.A. Beint
Department of Nursing Science, University of
Port Elizabeth
M.Cur
W.J. Kotze
Professor and Head, Department of Nursing
Science,
University of Port Elizabeth. D.Cur (Univer-
sity of Pretoria).
A.G.W. Nolle
Associate Professor, Department of Nursing,
Rand Afrikaans University. D. Litt. et Phil.
(UNISA)

